\title{
Comparison of Coal-, Coconut-, and Wood-Based Activated Carbons for Removal of Organic Matters in Wastewater Treatment Plant Effluent
}

\author{
Eunkwang Kwon ${ }^{\oplus}$. Soohyung Park ${ }^{\oplus} \cdot$ Wontae $^{\text {Lee }}{ }^{\dagger}$ \\ Department of Environmental Engineering, Kumoh National Institute of Technology
}

(Received March 28, 2021; Revised April 12, 2021; Accepted April 14, 2021)

Objectives: This study investigated the removal of dissolved organic materials by coal-, coconut-, and wood-based activated carbons to assess the addition of an activated carbon process to a publicly owned treatment works (POTW).

Methods: We assessed the removal of total organic carbon (TOC) by each process in the POTW, and examined the removal of TOC and $\mathrm{UVA}_{254}$ upon adding different amounts of coal-, coconut- and wood-based activated carbons $(50,100,200,300$, and $400 \mathrm{mg} / \mathrm{L})$ with various contact time $(10,20,30,60,120 \mathrm{~min})$.

Results and Discussion: Approximately $80 \%$ of TOC was removed throughout the POTW compared to the influent. The activated carbon adsorption tests of coagulated wastewater revealed that the removal rate of TOC and $\mathrm{UVA}_{254}$ from coal-based activated carbon was higher than those of coconut-based and wood-based activated carbons. The removal rate of dissolved organic materials was highest in ozone treated wastewater in all types of activated carbons, followed by ultraviolet disinfected wastewater and coagulated wastewater.

Conclusions: It was possible to remove an additional 35-55\% of dissolved organic materials upon addition of activated carbon to the treated wastewater although the removal depends on the material of the activated carbon, the injection amount, and the contact time. If an activated carbon process is adopted to the POTW, it can meet the effluent water quality standards (TOC).

Keywords: Activated Carbon, Effluent Limitation, TOC, Dissolved Organic Materials 


\title{
연구논문
}

\section{석탄, 야자, 목탄계 활성탄에 의한 하수처리수 유기물질 제거 비교}

\author{
권은광 ${ }^{\oplus} \cdot$ 박수형 $^{\circledR} \cdot$ 이원태 $^{\dagger}$
}

금오공과대학교 환경공학과

목적 : 본 연구는 하수처리시설 처리수의 유기물질 추가제거로 활성탄 흡착공정이 적합한지 확인하기 위해 활성탄 의 재질(석탄, 야자, 목탄)별 용존유기물질 제거율을 조사하였다.

방법: 하수처리시설의 공정별 총유기탄소(TOC) 제거현황을 파악하고, 총인(응집)처리수, 자외선 소독수, 오존처리 수를 대상으로 석탄, 야자, 목탄계 활성탄의 주입량 $(50,100,200,300,400 \mathrm{mg} / \mathrm{L})$ 과 반응시간 $(10,20,30,60,120$ $\min )$ 을 달리하여 흡착실험을 진행한 뒤 TOC, $\mathrm{UVA}_{254}$ 를 분석하였다.

결과 및 토의 : 하수처리시설 전체적으로는 유입수 대비 약 $80 \%$ 의 TOC가 제거되었다. 총인(응집)처리수의 활성탄 흡착 실험결과 석탄계 활성탄의 용존유기물질(DOC, $\left.\mathrm{UVA}_{254}\right)$ 제거율이 야자계와 목탄계 활성탄에 비하여 높게 나 타났다. 석탄계, 야자계, 목탄계 활성탄 모두 용존유기물질 제거율은 오존처리수에서 가장 높았고 다음으로 자외선 소독수, 총인처리수 순이었다.

결론 : 활성탄의 재질, 주입량, 접촉시간에 따라 용존유기물질 제거율이 달라지나 활성탄 주입으로 $35 \sim 55 \%$ 의 추가 적인 제거가 가능하였다. 조사대상 공공하수처리시설에 활성탄 흡착공정을 추가한다면 TOC로 전환되는 방류수 수 질기준을 충족하기에 문제가 없을 것이다.

주제어 : 활성탄, 방류수 수질기준, 총유기탄소, 용존유기물질

\section{1. 서론}

우리나라는 수질 및 수생태계를 보전하고 수인성 전염병을 예방하기 위해 공공하수처리시설의 방류수 수질기준을 설정 하여 유기물질, 부유물질, 총질소, 총인, 총대장균수와 생태독 성의 항목으로 나눠 그 농도를 규제하고 있다. 특히 유기물질 증가는 수중 산소를 소모하여 악취, 어류 폐사, 미관상 악화 등 자연 생태계에 큰 피해를 입힌다. ${ }^{1)}$ 공공하수처리시설 방류수 의 유기물은 생물화학적산소요구량(Biochemical Oxygen Demand, BOD)과 화학적산소요구량(Chemical Oxygen Demand, COD) 항목을 수질기준으로 설정하여 규제해 왔다.

하지만 $\mathrm{BOD}$ 측정은 미생물을 이용하기 때문에 분석값이 불안정하고 분해율이 낮아 측정에 어려움이 있고, 분석에 5 일 이상의 시간이 소요되어 오염사고가 발생하였을 때 즉각적인 대응이 어렵다는 단점이 있다.,3) 이를 보완하기 위해 과망간 산칼륨 $\left(\mathrm{COD}_{\mathrm{Mn}}\right)$ 이나 중크롬산칼륨 $\left(\mathrm{COD}_{\mathrm{Cr}}\right)$ 등을 이용하여 수 중 유기물질을 산화시키는 $\mathrm{COD}$ 가 도입되었으나, $\mathrm{COD}$ 역시 시료의 성상에 따른 산화율 차이가 크고 시료 내 일부 무기물 질과도 반응하기 때문에 재현성이 낮아 대표 지표로서 한계가
있다. ${ }^{4)}$ 또한, $\mathrm{BOD}$ 와 $\mathrm{COD}$ 는 직접적인 탄소량을 측정하는 것 이 아닌 수체의 유기탄소량을 산소 소모율로 환산하는 간접적 인 방법이므로 직접적인 유기탄소분석에 대한 필요성이 지속 적으로 제기되었다. ${ }^{5)}$ 특히 곧은 사슬 지방족탄화수소나 벤젠, 톨루엔, 피리딘과 같은 방향족탄화수소 화합물 등 분자량이 커서 생물에 의한 분해가 상대적으로 어려운 난분해성 유기물 질의 경우 $\mathrm{BOD}$ 와 $\mathrm{COD}$ 로 정확한 유기물질의 농도를 확인하 기 어렵다.)

이를 개선하고자 환경부는 2016년부터 하천의 생활환경 기준 중 유기물질 관리지표인 $\mathrm{COD}_{\mathrm{Mn}}$ 을 총유기탄소량(Total Organic Carbon, TOC)으로 전환하였고, 공공하수처리시설의 방류수수질기준도 $\mathrm{COD}_{\mathrm{Mn}}$ 에서 $\mathrm{TOC}$ 로 2021년부터 전환한다 (Table 1). ${ }^{7}$ TOC는 수중의 유기물질을 산화시켜 발생되는 이 산화탄소를 측정하여 탄소량으로 표현하는 방법으로 유기물 질이 공공수역에 미치는 영향을 직접적으로 측정할 수 있다. 또한, 측정이 간편하고 분석에 소요되는 시간이 기존 $\mathrm{COD}$ 분석에 비해 짧으며 난분해성 물질 등에 관계없이 유기물질의 총량을 알 수 있다는 장점이 있다. ${ }^{8)}$ 그러나, 기존 설치 및 운영 중인 공공하수처리시설은 방류수질 $\mathrm{COD}$ 기준으로 설계되어 
Table 1. Change of effluent limitation from COD to TOC for publicly owned treatment works (POTW) in Korea.

\begin{tabular}{|c|c|c|c|c|c|c|}
\hline \multirow{3}{*}{$\begin{array}{l}\text { Regulation parameter } \\
\text { (year) }\end{array}$} & \multicolumn{6}{|c|}{ Treatment capacity (C) and area classification } \\
\hline & \multicolumn{4}{|c|}{$C \geq 500 \mathrm{~m}^{3} / \mathrm{d}$} & \multirow{2}{*}{$50 \leq \mathrm{C}<500 \mathrm{~m}^{3} / \mathrm{d}$} & \multirow{2}{*}{$c<50 \mathrm{~m}^{3} / \mathrm{d}$} \\
\hline & Area grade I & Area grade II & Area grade III & Area grade IV & & \\
\hline $\begin{array}{l}\mathrm{COD}_{\mathrm{Mn}}(\mathrm{mg} / \mathrm{L}) \\
\text { (until 2020) }\end{array}$ & 20 & 20 & 40 & 40 & 40 & 40 \\
\hline $\begin{array}{l}\text { TOC (mg/L) } \\
\text { (from 2021) }\end{array}$ & 15 & 15 & 25 & 25 & 25 & 25 \\
\hline
\end{tabular}

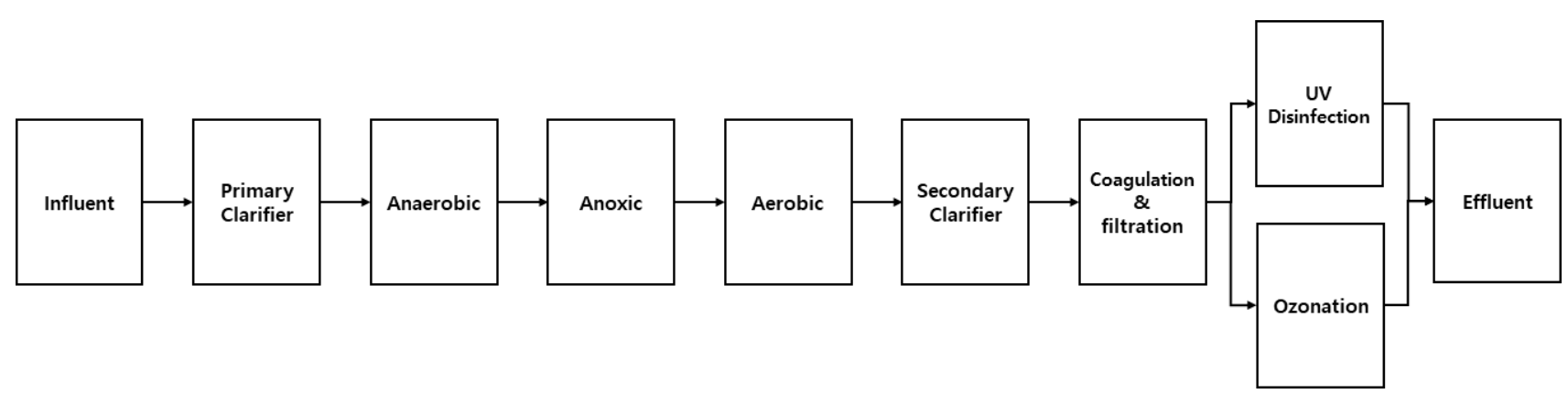

Fig. 1. Treatment process trains of the wastewater treatment plant studied.

방류수가 TOC 기준을 초과하는 경우가 발생될 수 있다. 특히 해당 시설에 난분해성 물질이 다량 함유된 하-폐수가 유입될 경우 그 분해율이 낮아 $\mathrm{COD}$ 로는 검출되지 않은 유기물질이 $\mathrm{TOC}$ 로는 검출될 수 있기 때문이다. 이러한 기존 하수처리시 설은 생물학적처리공정으로는 TOC 방류수질기준 준수에 한 계가 있어 난분해성 유기물질 제거를 위한 해결방안이 필요 하다.

하수의 난분해성 유기물질 제거를 위해 고도산화, 흡착, 응 집, 전기투석, 역삼투막여과 등 여러 가지 기술을 적용할 수 있지만, 본 연구에서는 초기투자 및 유지관리 비용이 적고 적 용성이 상대적으로 편리한 ${ }^{9}$ 활성탄흡착을 적용하여 하수처리 수의 TOC 제거능을 평가하였다. 활성탄 흡착에 의한 유기물 질 제거 연구는 국내외 많은 연구자들에 의해 수행되고 있지 만 정수 중 자연유기물질(Natural Organic Matter, NOM) 제거 에 대한 연구가 대부분이어서 연구결과를 하수처리수에 활용 하기에는 한계가 있다. 이에 본 연구를 통해 석탄, 야자, 목탄 계 활성탄에 의한 하수처리수 유기물질 제거를 비교하여 난분 해성 유기물질 유입으로 처리에 애로를 겪고 있는 공공하수처 리시설이 방류수수질기준(TOC)을 만족할 수 있는 처리 및 관 리방안을 마련하기 위한 기초자료로 활용하고자 한다.

\section{2. 실험방법}

\section{1. 대상 공공하수처리시설 및 채수}

조사대상인 $\mathrm{A}$ 하수처리시설의 공정별 유기물질 거동 및 제 거 현황을 파악하기 위하여 채수를 총 4 회 실시하였다. A 하 수처리시설의 시설용량은 $45,000 \mathrm{~m}^{3} /$ 일, 처리유량은 28,000 $\mathrm{m}^{3} /$ 일이었고, 시설용량대비 처리유량은 평균 $62 \%$ 이었다. 하 수처리시설의 유입수는 산업단지의 배출업체 폐수가 포함되 어 있으며, 이 중 일부 업체에서 제지폐수가 다량 유입되고 있어 하수처리에 어려움을 겪고 있다. 하수처리시설의 주요 공정은 침전지, 생물반응조(혐기조-무산소조-호기조), 총인 처리(응집처리), 여과처리, 오존처리 공정으로 이루어져 있 다(Fig.1).

\section{2. 활성탄 흡착실험}

하수처리시설의 생물학적처리 후 시료(응집처리수, UV 소 독수, 오존처리수)에 대해 분말활성탄(Powdered Activated Carbon, PAC)에 의한 유기물질 흡착실험을 수행하였다. 분말 활성탄은 J사의 석탄계, 야자계, 목탄계 3 종을 325 mesh 사이 즈로 걸러내어 흡착실험에 사용하였다. 활성탄 재질별 특성은

Table 2에 나타내었다. 활성탄의 비표면적은 야자계 $(1,155$ $\left.\mathrm{m}^{2} / \mathrm{g}\right)$ 와 목탄계 $\left(1,150 \mathrm{~m}^{2} / \mathrm{g}\right)$ 가 석탄계 $\left(1,050 \mathrm{~m}^{2} / \mathrm{g}\right)$ 보다 다소 넓었으나 큰 차이는 나지 않았다. 세공용적은 목탄계가 가장 컸고 야자계가 가장 적었다.

흡착실험은 $2 \mathrm{~L}$ 반응기에 활성탄을 주입농도별 $(50,100$, $200,300,400,500 \mathrm{mg} / \mathrm{L}$ )로 주입한 후 $100 \mathrm{rpm}$ 으로 교반시키 면서 반응시간 $(10,20,30,60,120 \mathrm{~min})$ 을 달리하며 수행하였 다. 모든 실험은 $20^{\circ} \mathrm{C}$ 로 항온 및 항습이 가능한 실험실에서 수행하였다.

\section{3. 분석방법}

채수한 시료는 $4^{\circ} \mathrm{C}$ 이하로 냉장 보관하면서 수질을 분석하 였으며, 분석에 다소 시간이 소요되는 시료의 경우 $\mathrm{pH} 2$ 이하 
Table 2. Characteristics of selected powdered activated carbons.

\begin{tabular}{ccccc} 
Property & Unit & \multicolumn{3}{c}{ Value } \\
\cline { 3 - 5 } Specific surface area $(\mathrm{BET})$ & $\mathrm{m}^{2} / \mathrm{g}$ & Coal-based PAC & Coconut-based PAC & Wood-based PAC \\
\hline lodine number & $\mathrm{mg} / \mathrm{g}$ & 950 & 1,155 & 1,150 \\
\hline Total pore volume & $\mathrm{cm}^{3} / \mathrm{g}$ & 0.603 & 1,055 & 1,050 \\
\hline $\mathrm{pH}$ & - & 7.8 & 0.504 & 0.896 \\
\hline Bulk density & $\mathrm{g} / \mathrm{mL}$ & 0.45 & 0.42 & 8.0 \\
\hline
\end{tabular}

로 낮춰 보관하였다. 공공하수처리시설의 유기물 거동 파악을 위한 시료는 수질오염공정시험기준에 따라 시료를 균질화 시 킨 후 입경 $300 \mu \mathrm{m}$ 체 거름을 하여 TOC를 분석하였다. 흡착 실험 시료는 실험 후 $\mathrm{GF} / \mathrm{F}$ (Glass fiber filters; pore $0.7 \mu \mathrm{m}$; Whatman, USA)로 여과하고 용존유기탄소(Dissolved Organic Carbon, DOC)와 $254 \mathrm{~nm}$ 의 자외선 흡광도 $\left(\mathrm{UVA}_{254}\right)$ 를 분석하 였다.

TOC는 총유기탄소분석기(TOC-LCPH/CPN, Shimadzu, Japan)를 이용하여 총탄소(Total Carbon, TC)에서 유기탄소 (Inorganic Carbon, IC)를 감하는 가감방법으로 분석하였다. $\mathrm{TOC}$ 분석간 지속적인 교반을 실시하여 입자의 침전을 방지 하였다. DOC도 같은 TOC 분석기로 분석하였으나, $\mathrm{GF} / \mathrm{F}$ 여과된 시료는 비정화성유기탄소(non-purgeable organic carbon, $\mathrm{NPOC}$ ) 법으로 분석하였다. UVA 254 는 UV-visible spectrophotometer (DR6000, HACH, USA)로 측정하였다.

\section{3. 결과 및 고찰}

\section{1. 하수처리공정의 TOC 제거}

Fig. 2는 연구대상 하수처리시설의 처리공정별 TOC 농도변 화를 나타낸다. 결과는 4 회 채수하여 분석한 값의 평균과 표 준편차로 표시하였다. 하수처리시설 유입수의 TOC 평균농도 는 $93.7 \mathrm{mg} / \mathrm{L}(90.7 \sim 101.6 \mathrm{mg} / \mathrm{L})$ 이며, 스크린 및 화학전처리 를 거친 1차 침전지 유출수에서 $57.6 \mathrm{mg} / \mathrm{L}(51.8 \sim 63.2 \mathrm{mg} / \mathrm{L})$ 로 유입수 대비 $38.5 \%$ 제거되었다. $\mathrm{A} 2 \mathrm{O}$ (혐기조/무산소조/호 기조) 공법을 사용하는 생물반응공정 후 TOC 농도는 39.4 $\mathrm{mg} / \mathrm{L}(32.7 \sim 46.0 \mathrm{mg} / \mathrm{L})$ 로 낮아져 유입수 대비 제거율은 $57.9 \%$ 로 나타났다. 하수처리시설의 생물반응조에서는 무산 소조 후단 부분에 폐타이어 담체를 충진한 유동성 생물막 공 정을 일부 적용하고 있으나 기존 생물반응조와 비교하였을 때 제거율 향상은 $5 \%$ 이하로 크지 않았다. ${ }^{10,11)} 2$ 차 침전지 유출수의 TOC 농도는 평균 $23.4 \mathrm{mg} / \mathrm{L}$ 로 유입수 대비 $75.0 \%$ 의 제거율을 나타냈다. 응집처리공정 유출수의 TOC 평균농 도는 $19.1 \mathrm{mg} / \mathrm{L}$ 로 2 차 침전지 유출수 $(23.4 \mathrm{mg} / \mathrm{L})$ 와 비교하여 제거율이 $4.6 \%$ 정도 향상된 값으로 나타나 현재 응집공정 $\left(\mathrm{Fe}\left(\mathrm{SO}_{4}\right)_{3}\right)$ 의 TOC 제거효율은 크지 않은 것으로 나타났다. 다만, 응집공정 후의 TOC 농도의 변화폭은 줄어들었다. 방류

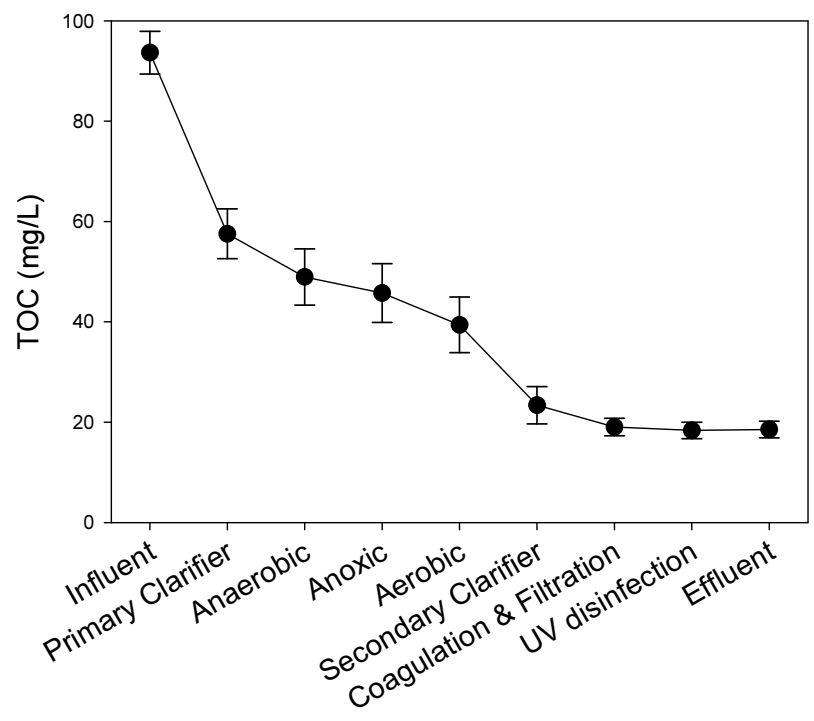

Fig. 2. Variations in TOC concentrations along the treatment processes in the POTW.

전의 마지막 처리공정인 자외선 소독(유출수 TOC 평균 18.4 $\mathrm{mg} / \mathrm{L}$ )과 오존산화공정(유출수 TOC 평균 $19.9 \mathrm{mg} / \mathrm{L}, \mathbf{F i g . 2}$ 에 표기되지 않음)도 TOC 제거율 향상에 미치는 영향이 크지 않았다.

\section{2. 총인처리수의 용존유기물질 흡착}

활성탄 재질에 따른 용존유기물질의 제거효율을 파악하기 위해 활성탄별 주입량 및 반응시간을 달리하여 제거율을 조사 하였다. Fig.3은 총인처리공정(응집/여과) 처리수를 대상원수 로 한 활성탄 흡착실험 결과로 활성탄 재질별 주입량 및 반응 시간에 따른 $\mathrm{DOC}$ 흡착특성을 나타낸다. 전반적으로 활성탄 의 재질과 상관없이 주입량이 많고 접촉시간이 길수록 DOC 제거율은 상대적으로 높게 나타났다.

총인처리수의 $\mathrm{DOC}$ 농도는 $13.3 \mathrm{mg} / \mathrm{L}$ 이었으며, 석탄계 활 성탄의 주입량을 $50 \mathrm{mg} / \mathrm{L}$ 로 하여 $10,20,30,60,120 \mathrm{~min}$ 으로 접촉시간을 증가시킨 경우 $\mathrm{DOC}$ 평균농도는 각각 $11.9,11.9$, $12.0,11.6,11.6 \mathrm{mg} / \mathrm{L}$ 로 낮아졌다. 야자계 활성탄의 주입량을 $50 \mathrm{mg} / \mathrm{L}$ 로 하여 $10,20,30,60$ 및 $120 \mathrm{~min}$ 반응하였을 경우 $\mathrm{DOC}$ 평균농도는 각각 $12.0,11.5,11.6,11.5,11.5 \mathrm{mg} / \mathrm{L}$ 이었 다. 목탄계 활성탄도 야자계 및 석탄계 활성탄과 동일한 조건 


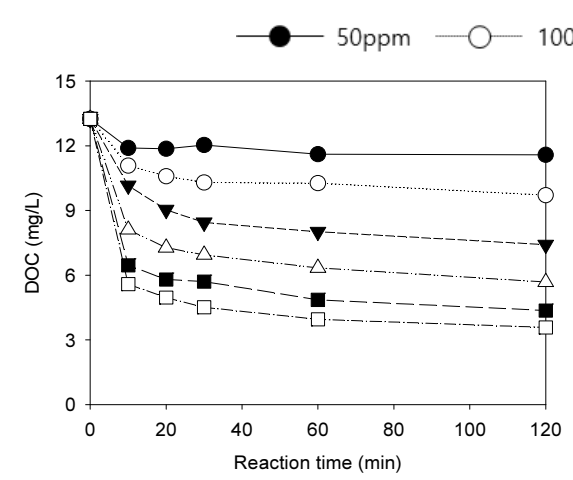

(a) Coal

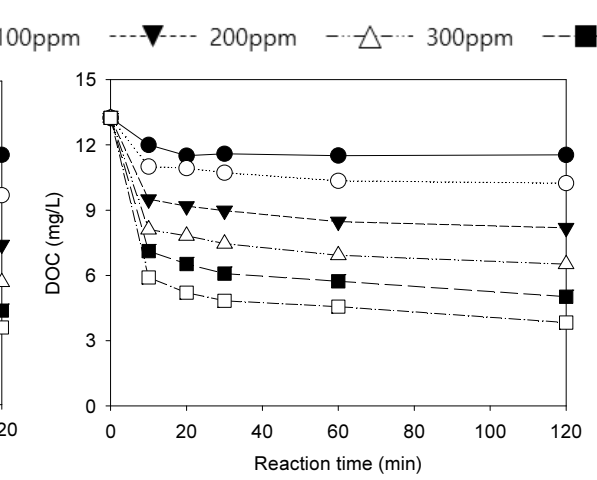

(b) Coconut

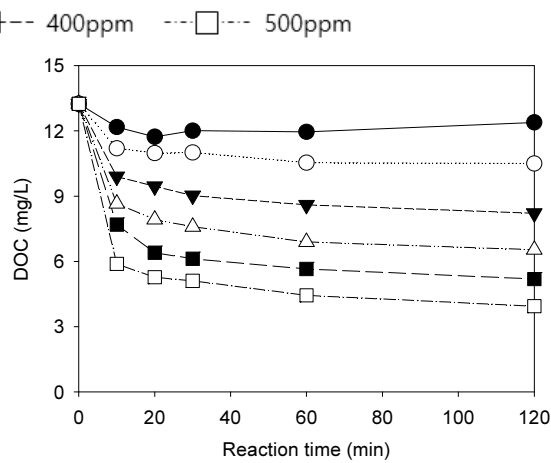

(c) Wood

Fig. 3. Effects of PAC source materials on the adsorption of DOC in coagulated wastewater.

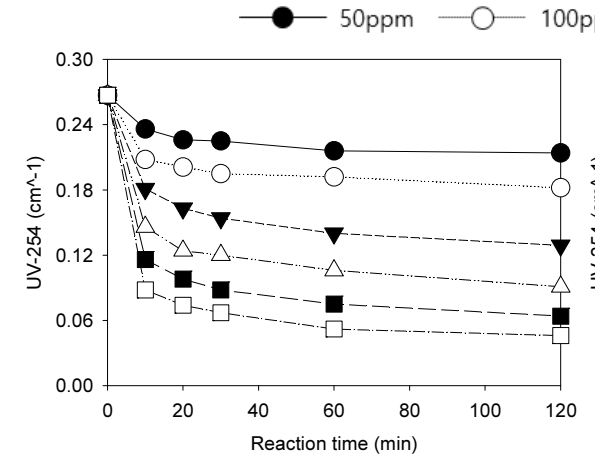

(a) Coal

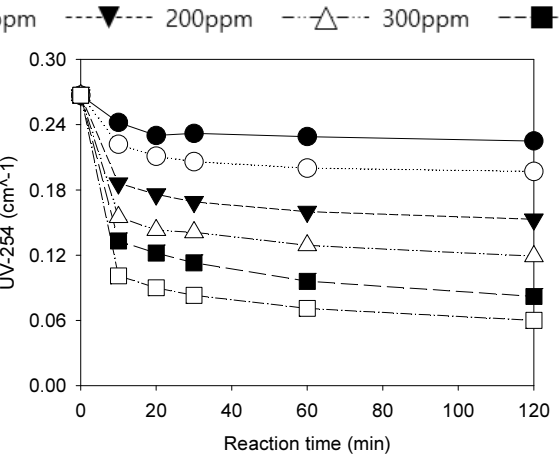

(b) Coconut

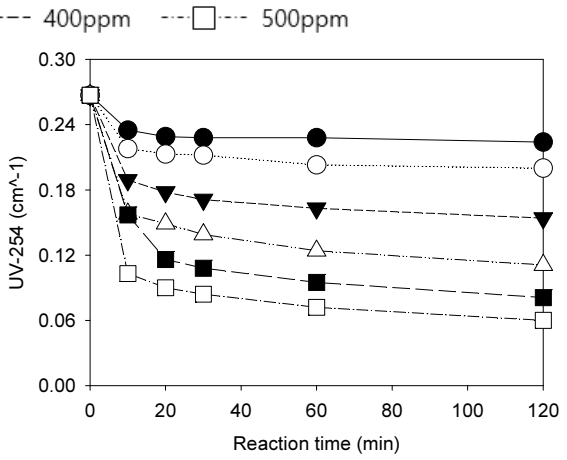

(c) Wood

Fig. 4. Effects of PAC source materials on the adsorption of UVA 254 in coagulated wastewater.

으로 실험을 진행하였고 $\mathrm{DOC}$ 평균농도는 각각 $12.2,11.7$, $12.0,12.0,12.4 \mathrm{mg} / \mathrm{L}$ 이었다. 활성탄 주입량 $50 \mathrm{mg} / \mathrm{L}$ 에서 석 탄계와 야자계 활성탄이 목탄계 활성탄에 비해 조금 높은 제 거율을 보였으나 활성탄 재질별로 $\mathrm{DOC}$ 제거에 미치는 영향 이 크게 나타나지 않았다.

활성탄 주입량을 $100,200,300,400,500 \mathrm{mg} / \mathrm{L}$ 로 증가시켜 실험한 결과 석탄계 활성탄의 DOC 제거율이 야자계와 석탄 계에 비하여 $5-10 \%$ 정도 높게 나타났다. 석탄계 활성탄 주입 량 $100,200,300,400,500 \mathrm{mg} / \mathrm{L}$ 에서 $120 \mathrm{~min}$ 흡착반응시킨 결과 $\mathrm{DOC}$ 제거율은 각각 $26.7 \%$ (야자계 $22.7 \%$, 목탄계 $20.8 \%$ ), $44.1 \%$ (야자계 $38.2 \%$, 목탄계 $38.0 \%$ ), $57.1 \%$ (야자계 $50.9 \%$, 목탄계 $50.7 \%$ ), $67.1 \%$ (야자계 $62.1 \%$, 목탄계 $60.8 \%$ ), $73.0 \%$ (야자계 $71.1 \%$, 목탄계 $70.3 \%$ )로 나타났다. 세 종류의 활성탄 중 목탄계의 세공용적(pore volume)이 가장 크나 흡착 능은 다른 재질의 활성탄에 비하여 낮게 나타났다. 이것은 하 수 내의 유기물질이 가지는 전하와 활성탄세공 표면전하의 관계 때문으로 추론된다. 목탄계 활성탄은 물의 $\mathrm{pH} 4$ 부근에 서 세공 표면전하가 0 부근이 되고 $\mathrm{pH}$ 가 증가할수록 표면 음 전하가 더욱 커진다. 따라서 $\mathrm{pH} 7$ 부근에서 활성탄 표면이 음전하를 띠고 있어 하수 중 유기물질(pH 7 부근에서 음전하) 과의 반발력으로 인해 흡착능이 낮아질 수 있다. ${ }^{12)}$ 또한 목탄 계 활성탄은 미세세공이 많은 반면 석탄계 활성탄은 중간세공
이 상대적으로 많아미 하수 내 분자량이 큰 $\mathrm{DOC}$ 물질을 흡착 하기에는 석탄계 활성탄이 용이할 수 있다. 그러나 활성탄을 장시간 사용할 경우 고분자성 유기물질이 활성탄의 공극을 폐 색시켜 흡착능력이 저하될 수 있으므로 ${ }^{14,15}$ 처리시설운영에 적용하기 전에 장기간 운전 시의 영향을 파악할 필요가 있다. $\mathrm{DOC}$ 흡착에서 나타난 이상의 경향은 $\mathrm{UVA}_{254}$ 흡착실험 결 과에서도 비슷하게 나타났다(Fig.4). 활성탄 주입량과 반응시 간을 달리하여 활성탄 재질별 흡착 제거율을 비교한 결과 활 성탄의 주입량이 많고 접촉시간이 길수록 $\mathrm{UVA}_{254}$ 유기물질의 제거율이 높게 나타났다. 다만, $\mathrm{UVA}_{254}$ 물질이 용존유기물질 중 흡착이 잘 되므로 DOC 제거율보다는 높은 제거율을 보였 다. 대상 원수를 총인공정 처리수로 하여 활성탄을 $500 \mathrm{mg} / \mathrm{L}$ 주입하고 $120 \mathrm{~min}$ 반응한 결과 $\mathrm{UVA}_{254}$ 제거율은 석탄계 $82.5 \%$, 야자계 $77.5 \%$, 목탄계 $77.5 \%$ 로 나타났다. 활성탄을 저농도 $(50 \mathrm{mg} / \mathrm{L})$ 로 주입하였을 때는 활성탄 재질별 유기물 제거율 이 크지 않았으나 주입량이 증가할수록 석탄계 활성탄의 제거 율이 높게 나타나는 것을 확인하였다.

\section{3. 자외선소독 및 오존주입이 용존유기물 흡착에 미치는 영향}

해당 하수처리시설은 총인처리 후에 자외선 소독(관로밀폐 형, 조사량 $\left.27 \mathrm{~mW} \cdot \mathrm{sec} / \mathrm{cm}^{2}\right)$ 을 하여 방류하는 경우와 오존처 리(주입량 $10 \sim 12 \mathrm{mg} / \mathrm{L}$, 접촉시간 $30 \mathrm{~min}$ )를 하여 방류하는 


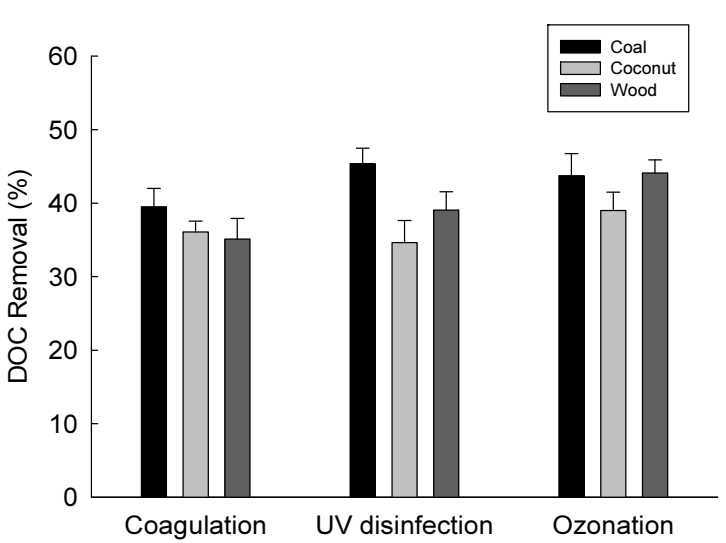

(a)

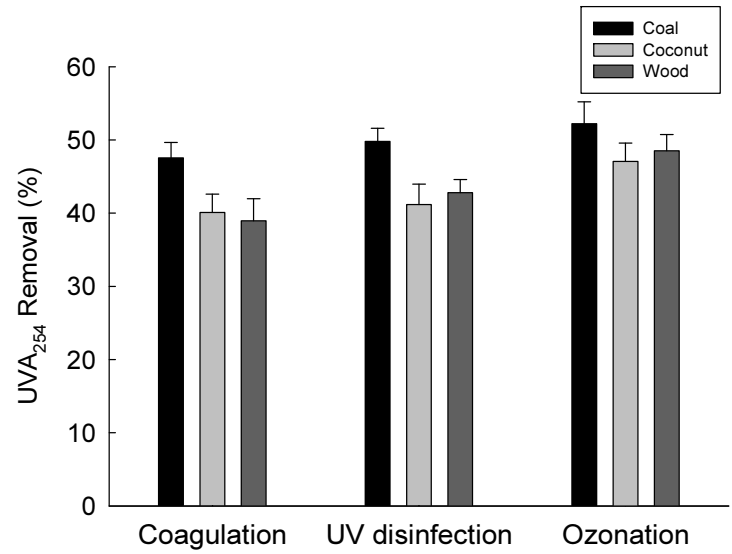

(b)

Fig. 5. Comparison of (a) DOC and (b) UVA 254 removal rates by different PACs (dose $=200 \mathrm{mg} / \mathrm{L}$, contact time $=60 \mathrm{~min}$ ).

경우가 있어 각각으로 처리된 하수에 대한 활성탄 흡착능을 평가하였다. 용존유기물의 소수성성분을 나타내는 척도인 고 유흡광도(SUVA: Specific UV Absorbance)는 총인처리수 2.0, 자외선 소독수 2.0 , 오존처리수 $1.3 \mathrm{~L} / \mathrm{mg} \cdot \mathrm{m}$ 로 자외선조사 및 오존산화에 의해 이중결합 및 방향족 탄소구조를 가진 유기물 비율이 감소된 것을 확인할 수 있었다. 자외선소독수와 오존 처리수에 대해서도 총인처리수와 같은 활성탄 주입량 및 반응 시간 조건에서 흡착실험을 하였다. 자외선소독수와 오존처리 수의 용존유기물질 제거경향은 Fig.3(DOC), Fig.4(UVA 254$)$ 와 유사한 경향을 보였다. 활성탄의 주입량이 많고 접촉시간 이 길수록 $\mathrm{DOC}$ 및 $\mathrm{UVA}_{254}$ 유기물질의 제거율이 높게 나타났 다. 다만, 자외선 소독수와 오존처리수에 대한 용존유기물질 흡착제거율이 총인(응집)처리수에 비해 1 $10 \%$ 높게 나타났 다. 자외선 소독수를 대상 원수로 하여 활성탄 흡착실험을 진 행하였을 때 석탄계 활성탄의 용존유기물 $\left(\mathrm{DOC}, \mathrm{UVA}_{254}\right)$ 제 거율이 다른 활성탄에 비해 상대적으로 높게 나타났다. 주입 량을 $50 \mathrm{mg} / \mathrm{L}$ 으로 하여 $10 \mathrm{~min}$ 반응하였을 때 $\mathrm{UVA}_{254}$ 제거율 은 석탄계 활성탄 $14.4 \%$, 야자계 활성탄 $10.3 \%$, 목탄계 활성 탄 $13.6 \%$ 로 나타났으며, 주입량을 $500 \mathrm{mg} / \mathrm{L}$ 으로 하여 120 $\min$ 반응하였을 때는 제거율이 각 $85.2 \%, 79.0 \%, 80.2 \%$ 로 나타났다. 오존처리수를 대상으로 흡착실험한 결과 활성탄 주 입량이 $50 \mathrm{mg} / \mathrm{L}$, 반응시간이 $10 \mathrm{~min}$ 일 때 $\mathrm{UVA}_{254}$ 제거율은 석탄계 활성탄 $7.4 \%$, 야자계 활성탄 $7.4 \%$, 목탄계 활성탄 $11.8 \%$ 로 나타났으며, $500 \mathrm{mg} / \mathrm{L}$ 의 농도로 $120 \mathrm{~min}$ 반응시켰 을 때 제거율은 석탄계 $79.3 \%$, 야자계 $74.5 \%$, 목탄계 $81.5 \%$ 로 목탄계 활성탄의 제거율이 높게 나타났다.

Fig. 5는 활성탄 주입량 $200 \mathrm{mg} / \mathrm{L}$ 으로 $60 \mathrm{~min}$ 접촉하였을 때 총인(응집)처리수, 자외선 소독수, 오존처리수에 대한 활 성탄 재질별 $\mathrm{DOC}$ 및 $\mathrm{UVA}_{254}$ 제거율을 나타낸다. 활성탄 종 류에 관계없이 자외선 소독과 오존처리를 한 경우 총인처리 수에 비하여 용존유기물질( $\left.\mathrm{DOC}, \mathrm{UVA}_{254}\right)$ 의 제거율이 높게 나타났다. 총인(응집)처리수의 경우 석탄계 활성탄의 $\mathrm{DOC}$
제거율이 $39.5 \%$ 로 가장 높았고 목탄계 활성탄의 DOC 제거 율이 $35.1 \%$ 로 가장 낮았다(Fig.5(a)). 자외선 소독수 역시 석 탄계 활성탄의 DOC 제거율이 $42.4 \%$ 로 가장 효율적인 것으 로 확인되었다. 다만 총인(응집)처리수에서 DOC 제거율이 가장 낮았던 목탄계 활성탄의 제거율이 자외선 소독수를 대 상으로 한 실험에서는 상대적으로 향상되어 가장 낮은 $\mathrm{DOC}$ 제거율을 보인 것은 야자계 활성탄(34.6\%)이었다. 오존처리 수의 경우도 야자계 활성탄이 $39.0 \%$ 의 DOC 제거율로 가장 낮았으며, 석탄계 활성탄이 $43.7 \%$, 목탄계 활성탄이 $44.1 \%$ 로 석탄계 및 목탄계 활성탄의 DOC 제거율이 유사하게 나 타났다. 이러한 경향은 $\mathrm{UVA}_{254}$ 물질의 제거실험에서도 유사 하게 나타났다. $\mathrm{DOC}$ 에 비해 증가율이 낮으나 자외선 소독 수와 오존처리수에 대한 목탄계 활성탄의 용존유기물질 제 거율이 향상되었다. 특히 오존처리수의 용존유기물질 제거 율이 총인(응집)처리수, 자외선 소독수에 비해 상대적으로 높게 나타났다. 이는 오존의 산화가 고분자성 물질의 분해 를 증가시켜 흡착에 의한 유기물질 제거를 향상시킨다는 선 행 연구와 유사한 결과를 보였다. ${ }^{16,17)}$ 오존 처리후 목탄계 활성탄의 용존유기물질 흡착능이 크게 향상되었는데, 이것 은 오존산화가 고분자물질을 저분자물질로 분해하여 상대 적으로 미세기공이 많은 목탄계 활성탄에 흡착이 용이하도 록 $^{13)}$ 하였기 때문으로 추론된다. 하지만 목탄계 활성탄은 고 분자 물질의 흡착에는 한계가 있었다. 오존처리수(SUVA 1.3 $\mathrm{L} / \mathrm{mg} \cdot \mathrm{m})$ 의 활성탄 흡착실험 후 처리수의 SUVA를 분석한 결과 석탄계와 야자계는 $1.1 \mathrm{~L} / \mathrm{mg} \cdot \mathrm{m}$ 이었으나 목탄계 활성 탄으로 처리된 물의 SUVA는 $1.2 \mathrm{~L} / \mathrm{mg} \cdot \mathrm{m}$ 로 상대적으로 높 은 수치를 나타내어 고분자물질의 흡착이 상대적으로 적었 음을 알 수 있었다.

\section{4. 결론}

본 연구에서는 공공하수처리시설의 방류수 수질기준 유기 
물질항목이 TOC로 전환되는 것을 대비해 하수처리공정별 $\mathrm{TOC}$ 제거현황을 파악하고 다양한 재질(석탄계, 야자계, 목탄 계)의 활성탄으로 처리수의 TOC 제거 가능성을 조사하였다.

1) 연구대상 공공하수처리시설의 유입수 대비 공정별 TOC 제거율은 전처리 및 1 차 침전에서 $38.5 \%$, 생물학적처리(A2O) $19.4 \%, 2$ 차 침전 $17.1 \%$, 총인(응집/여과)처리에서 $4.6 \%$ 로 관 측되었고, 자외선 소독이나 오존산화공정이 TOC 제거에 미 치는 영향은 미미하였다. 하수처리시설 전체적으로는 유입수 대비 약 $80 \%$ 의 $\mathrm{TOC}$ 가 제거되었다.

2) 총인처리수(응집/여과)의 활성탄 흡착 실험결과 석탄계 활성탄의 용존유기물질(DOC, $\mathrm{UVA}_{254}$ ) 제거율이 야자계와 목 탄계 활성탄에 비하여 높게 나타났고 이것은 세공의 표면전하 와 크기에 의한 것으로 추론된다.

3) 석탄계, 야자계, 목탄계 활성탄 모두 용존유기물질 제거 율은 오존처리수에서 가장 높았고 다음으로 자외선 소독수, 총인처리수 순으로 나타났다. 자외선 소독수와 오존처리수에 대한 용존유기물질(DOC, $\mathrm{UVA}_{254}$ ) 흡착제거율이 총인처리수 에 비해 $1 \sim 10 \%$ 높았다.

\section{Acknowledgement}

이 연구는 금오공과대학교 학술연구비로 지원되었습니다 (2018-104-061).

This research was supported by Kumoh National Institute of Technology (2018-104-061).

\section{References}

1. B. C. Kim, S. M. Jung, C. W. Jang, J. K. Kim, Comparison of BOD, COD and TOC as the indicator of organic matter pollution in streams and reservoirs of Korea, J. Korean Soc. Environ. Eng., 29(6), 640-643(2007).

2. S. J. Kang, B. J. Kang, K. H. Park, D. H. Jeong, W. S. Lee, H. M. Chung, Analysis of factors affecting effluent TOC in publicly owned treatment works, J. Korean Soc. Water Wastewater, 33(2), 141-150(2019).

3. H. Y. Park, J. K. Lee, H. Ha, H. B. Lee, Y. K. Kim, C. O. Park, S, I. Park, A correlation study of organic matters by TOC, in Proceedings of the Annual Meeting of Korean Society of Environmental Engineers, KSEE, Goyang, pp. 834-842(2006).

4. Y. B. Cho, Y. K. Oh, D. C. Shin, C. H. Park, Distribution of total organic carbon and correlations between organic matters of sewage treatment plants, J. Korean Soc. Environ. Anal., 17(4), 207-214(2014).

5. D. H. Jeong, I. C. Choi, Y. S. Cho, K. H. Ahn, H. M. Chung, O. S. Kwon, H. W. Park, H. S. Shin, J. Hur, Characteristics of TOC in effluent discharge from public sewage treatment works in Korea, J. Korean Soc. Water
Wastewater, 28(6), 657-688(2014)

6. I. W. Choi, J. H. Kim, J. K. Im, T. J. Park, S. Y. Kim, D. H. Son, I. A. Huh, D. H. Rhew, S. J. Yu, Application of TOC standards for managing refractory organic compounds in industrial wastewater, J. Korean Soc. Water Environ., 31(1), 29-34(2015).

7. H. W. Kim, M. J. Keon, Y. I. Choi, S. M. Choi, D. S. Lee, I. K. Kim, H. H. Kim, M. K. Song, B. G. Jung, Removal characteristics of organic matters in sewage secondary effluent by using pilot-scale coal-based granular activated carbon process, J. Korean Soc. Environ. Technol., 20(6), 425-431(2019).

8. D. H. Jeong, Y. S. Cho, K. H. Ahn, H. M. Chung, H. W. Park, H. S. Shin, J. Hur, D. H. Han, A study on the determination method of TOC effluent limitation for public sewage treatment plants, J. Korean Soc. Water Wastewater, 30(3), 241-251(2016).

9. M. J. Hwang, Y. S. Hwang, W. T. Lee, Phosphate adsorption on metal- impregnated activated carbon, J. Korean Soc. Environ. Eng., 37(11), 642-648(2015).

10. C. W. Na, H. H. Kim, J. S. Seo, Operation characteristics of sewage treatment plant by bio-SAC process in the winter time, in Proceedings of the Annual Meeting of Korean Society of Environmental Engineers, KSEE, Daejeon, pp. 783-789(2003).

11. Y. J. Jung, K. S. Min, Wastewater treatment performance of $\mathrm{A}^{2} / \mathrm{O}$ process with fluidized waste-tire media coated with activated carbon, J. Korean Soc. Environ. Eng., 25(10), 1299-1304(2003).

12. M. Bjelopavlic, G. Newcombe, R. Hayes, Adsorption of NOM onto activated carbon: effect of surface charge, ion strength and pore volume distribution, J. Colloid Interface Sci., 210, 271-280(1999).

13. H. Lee, H. Son, C. Lee, S. Bae, L. Kang, Effect of activated carbon types and service life on removal of odorous compounds: Geosmin and 2-MIB, J. Korean Soc. Environ. Eng., 29(4), 404-411(2007).

14. S. S. Kim, G. T. Seo, Effect of fluidized bed powdered activated carbon impregnated by iron oxide nano-particles on enhanced operation and NOM removal of MF membrane system, J. Korean Soc. Environ. Eng., 33(5), 332-339(2011).

15. T. Kameya, T. Hada, K. Urano, Changes of adsorption capacity and pore distribution of biological activated carbon on advanced water treatment, Water Sci. Technol., 35(7), 155-162(1998).

16. B. S. Oh, K. S. Kim, E. T. Lee, S. J. Na, J. W. Kang, A study on ozone decomposition and $\mathrm{OH}$ radical production in ozone/GAC process, J. Korean Soc. Environ. Eng., 25(11), 1465-1470(2003).

17. H. W. Ahn, S. H. Chae, C. K. Wang, J. L. Lim, Effect of ozonation on removal of dissolved organic matter by granular activated carbon process, J. Korean Soc. Environ. Eng., 30(6), 601-608(2008). 


\section{Declaration of Competing Interest}

The authors declare that they have no known competing financial interests or personal relationships that could have appeared to influence the work reported in this paper.

\section{Authors and Contribution Statement}

\section{Eunkwang Kwon}

Department of Environmental Engineering, Kumoh National Institute of Technology, Graduate Student, ORCID (1) 0000-00033483-7864: Data curation, Data analysis, Writing-original draft.

\section{Soohyung Park}

Department of Environmental Engineering, Kumoh National Institute of Technology, Researcher, ORCID (ㅇ 0000-0003-32337401: Validation, Visualization, Writing - review and editing.

\section{Wontae Lee}

Department of Environmental Engineering, Kumoh National Institute of Technology, Professor, ORCID (C) 0000-0001-96604455: Conceptualization, Supervision, Writing - review and editing. 